\section{In Vitro Conservation and Genetic Stability in Vanilla planifolia Jacks.}

José R. Bautista-Aguilar

Instituto de Biotecnología y Ecología Aplicada (INBIOTECA), Universidad Veracruzana, Av. de las Culturas Veracruzanas No. 101, Col. Emiliano Zapata, C.P. 91090, Jalapa, Veracruz, México; and Facultad de Ciencias Agrícolas, Universidad Veracruzana, Circuito Gonzalo Aguirre Beltrán s/n, Zona Universitaria, 91000 Xalapa, Veracruz, México

Lourdes G. Iglesias-Andreu

Instituto de Biotecnología y Ecología Aplicada (INBIOTECA), Universidad Veracruzana, Av. de las Culturas Veracruzanas No. 101, Col. Emiliano Zapata, C.P. 91090, Jalapa, Veracruz, México

\section{Jaime Martínez-Castillo}

Laboratorio de Marcadores Moleculares de la Unidad de Recursos Naturales del Centro de Investigación Científica de Yucatán, A.C. (CICY), Calle 43, Col. Chuburná de Hidalgo, C.P. 97200, Mérida, Yucatán, México

\section{Marco A. Ramírez-Mosqueda}

Facultad de Ciencias Biológicas y Agropecuarias, Universidad Veracruzana, C.P. 94950, Peñuela-Amatlán de los Reyes, Veracruz, México

\section{Matilde M. Ortiz-García}

Laboratorio de Marcadores Moleculares de la Unidad de Recursos Naturales del Centro de Investigación Científica de Yucatán, A.C. (CICY), Calle 43, Col. Chuburná de Hidalgo, C.P. 97200, Mérida, Yucatán, México

Additional index words. abscisic acid, temperature, genetic polymorphism, molecular markers

\begin{abstract}
Vanilla planifolia Jacks. is a species of great economic importance, since vanillin, a compound highly valued in the food and pharmaceutical industry, is extracted from its pods. This species is in the category of special protection, so it is important to take actions for its conservation and to maintain the genetic stability of the conserved germplasm. An adequate way to achieve this is through the minimal growth in vitro conservation techniques. The present work aimed to establish an in vitro conservation protocol for vanilla germplasm that allows the genetic stability of the conserved material. For the establishment of the minimal growth in vitro conservation protocol: two concentrations of basal Murashige and Skoog (MS) medium $(50 \%$ and $100 \%)$, two incubation temperatures $\left(4\right.$ and $\left.22{ }^{\circ} \mathrm{C}\right)$ and two concentrations of abscisic acid (ABA) ( 3 and $5 \mathrm{mg} \cdot \mathrm{L}^{-1}$ ) were evaluated. To evaluate the genetic stability of the germplasms used in this study (cultivated, wild, and $V$. insignis morphotypes) by analyzing the profiles of molecular markers SSR (simple sequence repeats) and ISSR (inter simple sequence repeats). The MS medium $(\mathbf{1 0 0 \% )}$ supplemented with $3 \mathrm{mg} \cdot \mathrm{L}^{-1}$ of $\mathrm{ABA}$ and incubated at $22{ }^{\circ} \mathrm{C}$, was the best treatment for the in vitro conservation of Vanilla spp. Compared with the control treatment, it allowed us to obtain smaller shoots $(1.17 \times 0.17 \mathrm{~cm})$, which showed high genetic stability, given by the low percentages of polymorphism detected in morphotypes cultivated and wild (SSR $0 \%$, ISSR $2 \%$ ) and $V$. insignis (SSR 0\%, ISSR $0 \%$ ). We conclude the usefulness of the established protocol to conserve the genetic variation of the evaluated Vanilla germplasm.
\end{abstract}

Received for publication 8 July 2021. Accepted for publication 18 Aug. 2021.

Published online 26 October 2021.

J.R.B.A. thanks the "Consejo Nacional de Ciencia y Tecnología" (CONACyT) by grants scholarship No. 593811.

L.G.I.A. is the corresponding author. E-mail: liglesias@uv.mx.

This is an open access article distributed under the CC BY-NC-ND license. illegal collection, to the point of bringing the species to the brink of extinction in their natural habitat (SEMARNAT, 2010; Soto-Arenas, 2006). For this reason, although $V$. planifolia is currently threatened with extinction, it is officially considered only in the category of special protection (SEMARNAT, 2010).

The area of vanilla culture is mostly composed of clones derived from the "Mansa" morphotype (Bory et al., 2007), which has low genetic variation (Minoo et al., 2007) largely due to its extensive vegetative propagation. For this reason, this crop has become vulnerable to various biotic and abiotic factors (Soto-Arenas, 1999), which has caused serious production losses in its plantations (Farreyrol et al., 2010). Therefore, conservation efforts are urgently needed.

One of the most effective strategies for the conservation of plant germplasm is based on the use of plant tissue culture techniques to help establish an in vitro germplasm bank (Kendon et al., 2017). In vitro conservation in the medium term, allows conserving aseptically, in a small area, many individuals under controlled conditions for several months, and even years (Cruz-Cruz et al., 2013). This type of in vitro conservation has been used successfully for the germplasm conservation of different plant species such as Solanum tuberosum L. (Gopal et al., 2005), Manihot esculenta Grantz. (Barrueto and Carvalho, 2008), Acanthostachys strobilacea (Schultes f.) Klotzsch (Carvalho et al., 2014), Asparagus racemosus Willd. (Thakur et al., 2015), Heliconia champneiana L. (Rodrigues et al., 2018), and Dillnia indica L. (Abd El-Kader et al., 2019) in the orchid Epidendrum chlorocorymbos Schltr. (LopezPuc, 2013). However, to establish an effective minimal growth in vitro conservation protocol, it is necessary to reduce the metabolism of plants. For this purpose, low temperatures and light intensity have been used, as well as the addition of osmotic compounds such as mannitol or sucrose, and different growth retardants in the culture medium (Rodrigues et al., 2018; Thakur et al., 2015; Trejgell et al., 2015).

Although in vitro conservation protocols have been established for $V$. planifolia (Bello-Bello et al., 2015; Divakaran et al., 2006), the genetic stability of conserved germplasm has not been evaluated yet. But genetic stability is an aspect of crucial importance to consider in the in vitro conservation protocols of germplasm because in vitro conditions may cause the appearance of physiological and biochemical alterations generated by genetic and epigenetic changes (Bednarek and Orłowska, 2019; Larkin and Scowcroft, 1981; Sánchez-Chiang and Jiménez, 2009). Some of these genetic changes have been evaluated by means of molecular markers (Sánchez-Chiang and Jiménez, 2009). The molecular markers SSR and ISSR have been some of the most used in the evaluation of the genetic stability of germplasm conserved 
in vitro of different plant species, such as Glycyrrhiza glabra L. (Mehrotra et al., 2012) and Tetrastigma hemsleyanum Diels et Gilg. (Peng et al., 2015).

The objective of this study was to develop an efficient protocol for minimal growth for the conservation in vitro of $V$. planifolia, for which we evaluated different treatments: basal MS concentrations $(50 \%$ and $100 \%)$, incubation temperatures $\left(4\right.$ and $22{ }^{\circ} \mathrm{C}$ ), and abscisic acid concentrations ( 3 and $5 \mathrm{mg} \cdot \mathrm{L}^{-1}$ ). Finally, we verify the usefulness of the best in vitro conservation treatment by evaluating the genetic stability of different Vanilla germplasm preserved in vitro using SSR and ISSR molecular markers.

\section{Materials and Methods}

Plant materials. We used two wild morphotypes of $V$. planifolia, "La Gran Lucha" and "Armadillo Chico," both from Oaxaca, Mexico, as well as the cultivated morphotype "Mansa" of $V$. planifolia and germplasm of $V$. insignis, a species genetically related to $V$. planifolia, which also has outstanding characteristics (Bory et al., 2008), particularly for its greater tolerance to pathogen attack and water deficit (Soto-Arenas, 1999). Originating from the latter, from the locality of "Emiliano Zapata," Veracruz, Mexico. All of these were previously established in vitro, in the plant tissue culture laboratory, at the Institute of Biotechnology and Applied Ecology (INBIOTECA), Universidad Veracruzana, Xalapa, Veracruz, Mexico.

In vitro conservation. For in vitro conservation by minimal growth, shoots of $V$. planifolia morphotype "Mansa" $(\approx 0.5-0.8 \mathrm{~cm}$ in length) were transferred to test tubes $(22 \times$ $220 \mathrm{~mm}$ ) containing $10 \mathrm{~mL}$ of MS culture medium (Murashige and Skoog, 1962), without plant growth regulators (RCVs). Phytagel (Sigma-Aldrich, St. Louis, MO) of concentration $2.2 \mathrm{~g} \cdot \mathrm{L}^{-1}$ was used as the gelling agent. Two concentrations $(50 \%$ and $100 \%)$ of the MS culture medium, as well as two concentrations $\left(0,3\right.$, and $\left.5 \mathrm{mg} \cdot \mathrm{L}^{-1}\right)$ of $\mathrm{ABA}$ (Sigma-Aldrich) were evaluated. In addition, the effect of two incubation temperatures $\left(4 \pm 2\right.$ and $\left.22 \pm 2{ }^{\circ} \mathrm{C}\right)$ on the in vitro conservation of $V$. planifolia was evaluated. The $\mathrm{pH}$ of the culture media was adjusted to 5.8 with $0.5 \mathrm{~N} \mathrm{NaOH}$ and subsequently sterilized at $121^{\circ} \mathrm{C}$ for $15 \mathrm{~min}$ in an autoclave (FE-299 Felisa, San Juan de Ocotán Zapopan, Jalisco, México) at $1.5 \mathrm{~kg} \cdot \mathrm{cm}^{-2}$. All cultures were maintained under a light irradiation of $50 \pm 5$ $\mu \mathrm{mol} \cdot \mathrm{m}^{-2} \cdot \mathrm{s}^{-1}$, provided by fluorescent lamps and a photoperiod ( $16 \mathrm{~h}$ light $/ 8 \mathrm{~h}$ dark). After $120 \mathrm{~d}$ of cultivation, the percentage of survival, the length of shoots, the number of leaves, and the length and number of roots were evaluated.

Statistical analysis. All experiments were run using a randomized, repeated twice design with 30 replicates each (each replicate consisted of a tube with $10 \mathrm{~mL}$ of culture medium), and one explant (nodal segments or individual shoots). The data obtained was processed statistically with the IBM SPSS
Statistics (version 25) software. An analysis of variance followed by a Tukey's test $(P \leq$ $0.05)$ was performed. Normality and variance homogeneity were checked by the Kolmogorov-Smirnov and Levene tests, respectively. The data for the variables stem length and root length required transformation to natural logarithm $(\mathrm{LN})$. Shoots, previously rooted in vitro, of 8-10 cm long, were rinsed with tap water. These were subsequently planted in $50 \times 30 \times$ $5 \mathrm{~cm}$ trays, containing a sterile substrate consisting of a 1:1 ratio of peatmoss and Agrolite substrate. The in vitro plantlets were grown in greenhouse conditions under $50 \%$ shade, an $80 \%$ to $95 \%$ relative humidity, and a temperature between 28 and $32{ }^{\circ} \mathrm{C}$. The in vitro plantlets were watered with tap water three times a week and fertilized once a week with the (Nitrofoska, Santiago de Querétaro, México) foliar fertilizer $(25 \mathrm{~N}-10 \mathrm{P}-17 \mathrm{~K})$. After 8 weeks of cultivation in the greenhouse, the survival rate of acclimatized in vitro plantlets was recorded.

Evaluation of genetic stability. We evaluated the genetic stability of different germplasms after $120 \mathrm{~d}$ of being subjected to the best treatment for conservation with $\mathrm{ABA}(V$. planifolia wild morphotypes from "La Gran Lucha" and "Armadillo Chico," V. planifolia cultivated morphotype "Mansa" and $V$. insig$n i$ Ames).

Extraction of DNA. Total DNA was extracted from $0.2 \mathrm{~g}$ of leaf tissue, from 10 shoots per treatment, using the protocol of Doyle and Doyle (1987). The concentration and purity of the extracted DNA was determined on a spectrophotometer (ultraviolet) (JENWAY, Staffs, UK) and its integrity was evaluated by horizontal electrophoresis (CONSORT) in $0.8 \%$ agarose gels, stained with ethidium bromide $\left(1 \mathrm{mg} \cdot \mathrm{L}^{-1}\right)$ and observed on a ultraviolet light transilluminator (UVP MultiDoc-It, Cambridge, UK).

Amplification of SSR and ISSR markers. Fourteen SSR primers (mVplCIR002, mVplCIR003, mVplCIR005, mVplCIR010, mVplCIR015, mVplCIR016, mVplCIR019, mVplCIR022, mVplCIR025, mVplCIR026, mVplCIR028, mVplCIR031, mVplCIR047, mVplCIR050) (Bory et al., 2008) and 10 ISSR primers (A04, C01, C02, C03, C07, C08, C09, C10, T05, T06) (Martínez-Castillo et al., 2008; Verma et al., 2009) were evaluated. The amplification reactions were performed in a final volume of $25 \mu \mathrm{L}$, containing $40 \mathrm{ng}$ of genomic DNA, $2.5 \mu \mathrm{L}$ of $10 \mathrm{X}$ PCR buffer, $0.2 \mathrm{~mm}$ of deoxynucleoside triphosphate, $0.2 \mu \mathrm{M}$ of each pair of SSR primers or each ISSR primer examined, $2 \mathrm{~mm}$ magnesium chloride $\left(\mathrm{MgCl}_{2}\right)$, and $0.5 \mathrm{U}$ of Taq DNA polymerase (INVITROGEN, Waltham, MA). The amplification of the DNA fragments was performed in a Thermocycler (GenAmp PCR System 9700; Applied Biosystems, Foster City, CA). The amplification program for the SSR consisted of $4 \mathrm{~min}$ at $94^{\circ} \mathrm{C}$ for initial denaturation, 34 cycles of $30 \mathrm{~s}$ at $94{ }^{\circ} \mathrm{C}$ for denaturation, $45 \mathrm{~s}$ for annealing based on the temperatures required for each pair of primers (Table 1), 1 min extension at $72^{\circ} \mathrm{C}$, and a final extension at $72^{\circ} \mathrm{C}$ for $5 \mathrm{~min}$. The amplification program for the ISSR consisted of $7 \mathrm{~min}$ at $94^{\circ} \mathrm{C}$, for initial denaturation, 34 cycles of $30 \mathrm{~s}$ at $94^{\circ} \mathrm{C}$, for denaturation, $45 \mathrm{~s}$ for annealing, based on the temperatures required for each primer, and an extension at $72^{\circ} \mathrm{C}$, for 1:30 min, and a final extension at $72^{\circ} \mathrm{C}$, for 10 min.

Separation, visualization, and analysis of amplified products. The amplified products (SSR and ISSR) were separated into $6 \%$ and $5 \%$ polyacrylamide gels respectively. A $1 \mathrm{X}$ Tris Borate EDTA (TBE) buffer solution [89 mM Tris-hydroxymethyl-aminomethane (Tris), $89 \mathrm{~mm}$ boric acid $\left(\mathrm{H}_{3} \mathrm{BO}_{3}\right)$, and $2 \mathrm{~mm}$ ethylenediaminetetraacetic acid (EDTA)] was used. The gels were loaded with $5 \mu \mathrm{L}$ of PCR product added with $4 \mu \mathrm{L}$ of bromophenol blue.

The size of the SSR alleles was determined using a 10-bp reference marker (INVITROGEN 1821-015). The electrophoretic separation was performed for $4 \mathrm{~h}$ at $320 \mathrm{~V}$ in a vertical electrophoresis chamber (SQ3 sequencer; Hoefer Scientific Instruments, San Francisco, CA). Similarly, the detection of the ISSR markers by electrophoresis was performed for $12 \mathrm{~h}$ at $320 \mathrm{~V}$, using the same vertical electrophoresis chamber and a 123-bp DNA ladder (Axygen, Glendale, AZ). Consequently, each of the gels was revealed, fixed, and dried using the silver staining technique, based on the methodology of Martínez-Castillo et al. (2008).

The fragments amplified with the ISSR primers were recorded in a binary base matrix with values of 0 and 1 , where 1 indicates the presence and 0 indicates the absence of bands. The fragments amplified with the SSR primers were recorded in a genotypic matrix. For this purpose, the number and frequency of alleles for each locus were recorded by coding them according to their total size in bp. The size of the SSR alleles was determined with a 10-bp DNA ladder as a reference (INVITROGEN), which was placed between samples during the electrophoresis. Only the SSR and ISSR bands that showed high resolution and reproducibility were recorded. Each band obtained was considered an independent locus. For both markers (SSR and ISSR), the percentage of polymorphic loci was calculated as well as the number and frequency of alleles for each locus based on their total size in bp. A similarity matrix was calculated using Jaccard's coefficient and the dendrogram was generated using the unweighted pair group method (UPGMA). The clustering method was evaluated by bootstrap analysis with 1000 replicates using the PAST program (PAleontological Statistics, Version 2.17) (Hammer et al., 2001).

\section{Results}

In vitro conservation by minimal growth. Shoots of $V$. planifolia preserved in vitro at $4 \pm$ $2{ }^{\circ} \mathrm{C}$ showed high sensitivity to low temperatures, since after 3 weeks of cultivation, at this temperature there was a $100 \%$ reduction in shoot survival, regardless of the concentrations of MS and ABA treatments examined (Fig. 1). Significant differences were observed between the treatments incubated at a temperature of $22 \pm 2{ }^{\circ} \mathrm{C}$ (Table 1). The 
Table 1. Effect of abscisic acid (ABA) and Murashige and Skoog (MS) concentrations on the in vitro conservation of Vanilla planifolia.

\begin{tabular}{|c|c|c|c|c|c|}
\hline Treatments & Survival (\%) & Length $(\mathrm{cm})$ & Number of leaves & Number of roots & Length of roots $(\mathrm{cm})$ \\
\hline$\overline{\mathrm{MS}}$ & 100.0 & $2.58 \pm 0.13 \mathrm{D}$ & $2.67 \pm 0.33 \mathrm{AB}$ & $2.00 \pm 0.15 \mathrm{~A}$ & $1.72 \pm 0.44 \mathrm{D}$ \\
\hline $\mathrm{MS}+3 \mathrm{mg} \cdot \mathrm{L}^{-1} \mathrm{ABA}$ & 93.3 & $1.10 \pm 0.17 \mathrm{~B}$ & $1 \pm 0.45 \mathrm{~A}$ & $2.00 \pm 0.58 \mathrm{~A}$ & $0.79 \pm 0.20 \mathrm{~B}$ \\
\hline $\mathrm{MS}+5 \mathrm{mg} \cdot \mathrm{L}^{-1} \mathrm{ABA}$ & 66.7 & $0.71 \pm 0.16 \mathrm{~A}$ & $1.17 \pm 0.40 \mathrm{~A}$ & $0.67 \pm 0.33 \mathrm{~A}$ & $0.40 \pm 0.10 \mathrm{~B}$ \\
\hline $1 / 2 \mathrm{MS}$ & 100.0 & $3.03 \pm 0.24 \mathrm{E}$ & $3.67 \pm 0.21 \mathrm{~B}$ & $1.00 \pm 0.10 \mathrm{~A}$ & $1.67 \pm 0.43 \mathrm{CD}$ \\
\hline $1 / 2 \mathrm{MS} 3 \mathrm{mg} \cdot \mathrm{L}^{-1} \mathrm{ABA}$ & 80.0 & $1.63 \pm 0.18 \mathrm{C}$ & $2.67 \pm 0.33 \mathrm{AB}$ & $2.33 \pm 0.33 \mathrm{~A}$ & $1.11 \pm 0.29 \mathrm{C}$ \\
\hline $1 / 2 \mathrm{MS} 5 \mathrm{mg} \cdot \mathrm{L}^{-1} \mathrm{ABA}$ & 60.0 & $1.08 \pm 0.21 \mathrm{BC}$ & $1.20 \pm 0.20 \mathrm{AB}$ & $1.00 \pm 0.10 \mathrm{~A}$ & $0.21 \pm 0.05 \mathrm{~A}$ \\
\hline
\end{tabular}

The values represent the mean \pm SE. Means with different letters were significantly different (Tukey, $P \leq 0.05)$.

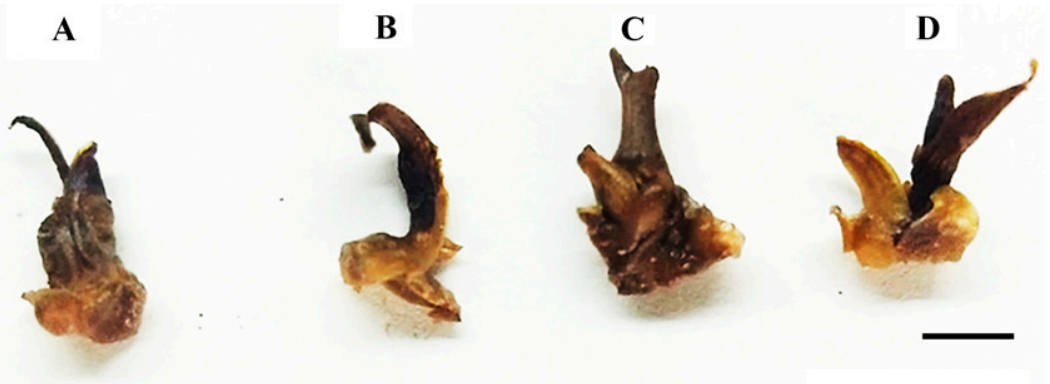

Fig. 1. Temperature effect on Vanilla planifolia at $4{ }^{\circ} \mathrm{C}$. Bar $=1 \mathrm{~cm}$. (A) $50 \% \mathrm{MS},(\mathbf{B}) 100 \% \mathrm{MS},(\mathbf{C})$ $100 \% \mathrm{MS}+3 \mathrm{mg} \cdot \mathrm{L}^{-1}$ of abscisic acid (ABA), and (D) $100 \% \mathrm{MS}+5 \mathrm{mg} \cdot \mathrm{L}^{-1}$ of ABA.

highest survival rates $(100 \%)$ were obtained in the control, $100 \% \mathrm{MS}$, and $50 \%$ MS treatments. However, the development variables were unaffected by the treatment. On the other hand, the ABA concentrations used produced a reduction in the length of shoots, length, and number of roots, as well as the number of leaves. Therefore, the highest survival percentage using ABA (93.3\%) was observed in MS medium added with 3 $\mathrm{mg} \cdot \mathrm{L}^{-1} \mathrm{ABA}$. Shoots cultivated on this treatment showed a stem length of $1.1 \mathrm{~cm}$, with 0.67 roots showing a length of $0.79 \mathrm{~cm}$ after $120 \mathrm{~d}$ of cultivation (Fig. 2). A $100 \%$ survival was observed from shoots that came from the material conserved in $\mathrm{MS}+3 \mathrm{mg} \cdot \mathrm{L}^{-1} \mathrm{ABA}$ 4 weeks after the transfer of the in vitro plantlets to greenhouse conditions.

Assessment of genetic stability. Of the 10 ISSR primers tested, only 6 of them ( $\mathrm{C} 03$, A04, T05, T06, C07, C09) produced clear and reproducible bands in a molecular weight range between 347 and 2,214 bp. Although a total of 51 bands were obtained, only 4 of them were found to be polymorphic, representing $2 \%$ of the genetic polymorphism detected in the in vitro plantlets of "La Gran Lucha," "Armadillo Chico," and the morphotype "Mansa" conserved by minimum growth, which were evaluated in this way. However, for $V$. insignis, a total of 49 bands were detected, whose molecular weight varied between 394 and $2460 \mathrm{bp}$, but all were monomorphic (Table 2).

Of the 14 SSR primers evaluated, only 8 of them (mVplCIR002, mVplCIR010, mVplCIR015, mVplCIR016, mVplCIR019, mVplCIR025, mVplCIR031, mVplCIR047) produced distinctive and reproducible bands. These primers threw a total of 12 bands for "La Gran Lucha," "Armadillo Chico," and the morphotype "Mansa". Regarding $V$. insignis, a total of 9 bands were obtained. The $\mathrm{mVpICR} 016$ primer was discarded because it

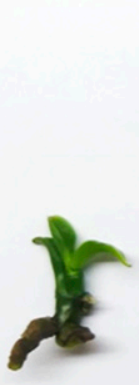

(A)

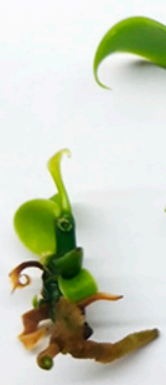

(B)

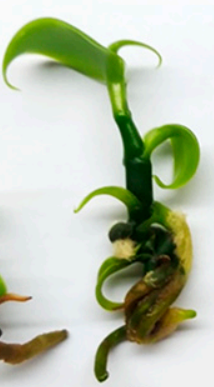

(C)

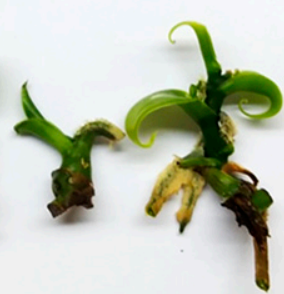

(D)

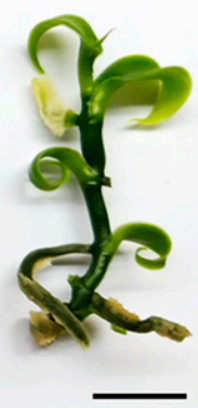

(F)

Fig. 2. Effect of the concentration of MS medium and abscisic acid (ABA) on the in vitro conservation of Vanilla planifolia Jacks. MS (A) 5 , (B) 3 , and (C) $0 \mathrm{mg} \cdot \mathrm{L}^{-1}$ of ABA from left to right and $50 \%$ MS (D) 5, (E) 3, and (F) $0 \mathrm{mg} \cdot \mathrm{L}^{-1}$ of ABA from left to right. Bar $=1 \mathrm{~cm}$.

did not produce good-quality amplification. The molecular weight range of the bands obtained was 215-346 bp (Table 2). It was of interest to observe the presence of a great monomorphism in the SSR profiles of $100 \%$ obtained in the preserved $V$. planifolia seedlings, which apparently evidences their genetic stability. The results of the dendrograms obtained from the UPGMA clusters analysis based on Jaccard similarity coefficients revealed high genetic similarity between clustering patterns of SSR and ISSR (Fig. 3).

\section{Discussion}

Various osmotic and growth-regulating agents have been evaluated for the preservation of Vanilla spp. (Bello-Bello et al., 2015; Divakaran et al., 2006). However, the effects of low temperatures, high doses of growth inhibitors, and the genetic stability of the preserved material have not yet been evaluated.

Some authors (Divakaran et al., 2006; Engelmann 2011) have indicated that the use of low temperatures of 0 to $10^{\circ} \mathrm{C}$ is an effective way to reduce the growth rate in in vitro conservation work. However, it has been indicated (Lambardi et al., 2006) that the most appropriate incubation temperature to use in in vitro conservation work for minimum growth depends on each species under study. It is possible that the sensitivity to low temperatures shown by $V$. planifolia shoots incubated at low temperatures is because, as this species usually grows in tropical and subtropical climates, at temperatures between 20 and $30^{\circ} \mathrm{C}$ (Ranadive, 2005), it is not able to show adequate tolerance to low temperatures.

A beneficial effect on the reduction of mineral element content in the culture medium was not observed, as expected, considering the results obtained by Lopez-Puc (2013), who found that $1 / 2$ MS was effective for the conservation of the orchid Epidendrum chlorocorymbos Schltr. Other authors, such as Ramírez-Mosqueda et al. (2019), found that the use of 3/4 MS was equally effective for the conservation of the orchid Laelia anceps Lindl.

ABA is a plant growth inhibitor that has been widely used in in vitro conservation programs for different crops of agri-food, pharmaceutical, and ornamental interest. It was used for this purpose in some species, such as Garcinia mangostana $\mathrm{L}$. and Lansium domesticum Corr. (Keatmetha et al., 2011), Saccharum spp. (Bello-Bello et al., 2014), and Dillnia indica L. (Abd El-Kader et al., 2019). ABA has different physiological effects on plants, among which are the inhibition of plant elongation and cell 
Table 2. Analysis of the genetic stability of Vanilla germplasm conserved in vitro by minimum growth evaluated with inter simple sequence repeat (ISSR) and simple sequence repeat (SSR) markers.

ISSR markers

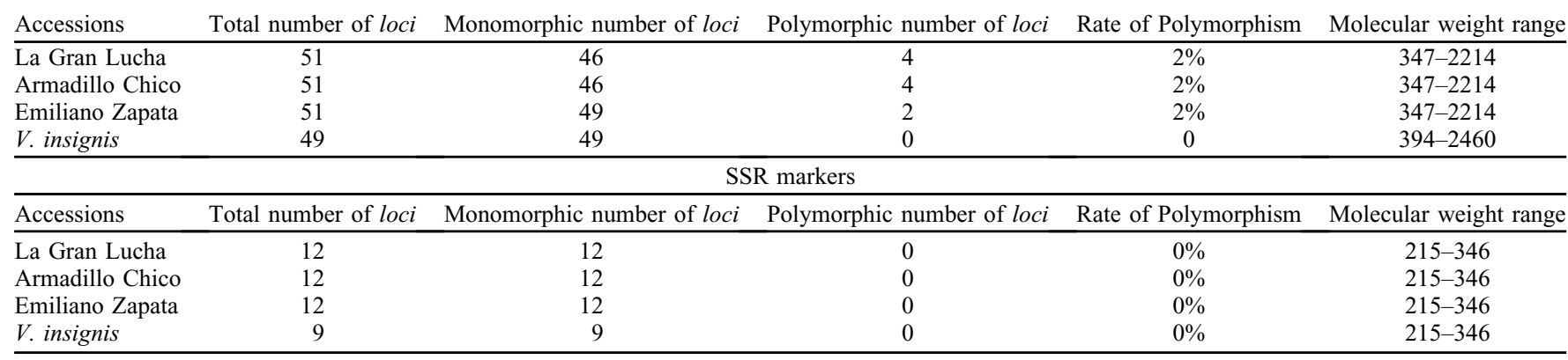

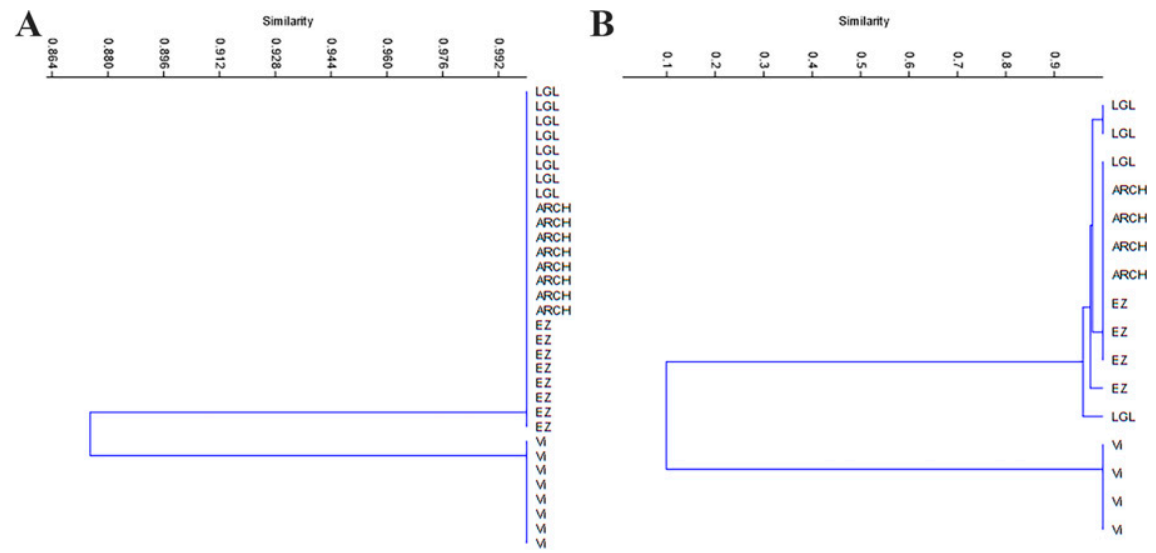

Fig. 3. Dendrogram of Vanilla spp. based on the Jaccard's coefficient of (A) inter simple sequence repeat and $(\mathbf{B})$ simple sequence repeat markers.

division, stomatic occlusion, induction of seed dormancy, and prevention of premature germination (Li et al., 2015; Selvakumar et al., 2016).

In our study, $\mathrm{ABA}$, at a concentration of 3 $\mathrm{mg} \cdot \mathrm{L}^{-1}$, produced a reduction in the in vitro growth of $V$. planifolia. These results coincide with those obtained by Bello-Bello et al. (2015), which highlighted the beneficial effect of the addition of ABA on the conservation of minimal growth of $V$. planifolia. However, these authors did not evaluate if the proposed protocol affected the genetic stability of the germplasm conserved in vitro.

The analysis of the genetic stability of the materials preserved in vitro is essential because during the conservation process, somaclonal variants may arise that cause alterations in the genetic homogeneity of the conserved germplasm (Tyagi et al., 2010). In $V$. planifolia, there are few studies on the analysis of somaclonal variation in micropropagated plants. In this regard, the presence of $71.66 \%$ of genetic polymorphism in in vitro plantlets of this species regenerated by indirect organogenesis has been reported (Ramírez-Mosqueda and Iglesias-Andreu, 2015) and more than $15 \%$ of polymorphism from the sixth subculture in micropropagation works in $V$. planifolia (Pastelín-Solano et al., 2019). Studies of genetic stability in cryopreservation using ISSR primers have revealed that the composition of the medium and the number of subcultures influence genetic stability (IsidroAdolfo et al., 2019). However, studies on the genetic stability of the germplasm of these species conserved in vitro are limited.

Previous studies carried out by BorbollaPérez et al. (2016) to detect the variation in the SSR profiles of two $V$. planifolia plantations from "Papantla," Veracruz, Mexico, showed the presence of $18.18 \%$ of genetic polymorphism, even though the plants analyzed came from the clonal propagation of the "Mansa" morphotype. This evidence the genetic variability of some $V$. planifolia plants used as donors of explants in this study.

The integral analysis of the results obtained with both molecular markers allow us to conclude that genetic stability was maintained not only in commonly cultivated $V$. planifolia (Mansa), but also in its wild germplasm and in $V$. insignis germplasm, by minimal growth. This result could be useful for increasing the subculture period from 45 to $120 \mathrm{~d}$ without any genetic alterations. However, it is recommended to carry out future studies to evaluate, with other molecular markers, such as methylation-sensitive-Amplified Fragment Length Polymorphism, the possible epigenetic variations that could have arisen in the germplasm of Vanilla preserved by the procedure of minimum growth in vitro established in this work.

In conclusion, MS media containing 3 $\mathrm{mg} \cdot \mathrm{L}^{-1}$ of ABA allows to obtain survival of $93.3 \%$, lower height and length of the roots, so it can be used for in vitro conservation by minimum growth of germplasm of $V$. planifolia. Under these conservation conditions, minimal variation genetic was detected by ISSR and SSR markers in different germplasms of Vanilla spp. Therefore, the use of the in vitro conservation protocol established to conserve, in the medium term, this valuable genetic resource with adequate genetic stability is recommended.

\section{Literature Cited}

Abd El-Kader, S.M., M.F. Hwida, and D.G. Aseel. 2019. In vitro conservation of the unique Dillenia indica grown in Egypt under minimal-growth conditions. Egypt. J. Agr. Res. 97:249-264, https://journals.ekb.eg/article_68656_81b0d13d2c 2c0dd0add216f765ef 2335 .

Barrueto, L.P. and C.B. Carvalho. 2008. Importance of abscisic acid (ABA) in the in vitro conservation of cassava (Manihot esculentus). Chil. J. Agr. Res. 68:304-308, https://doi.org/ 10.4067/S0718-58392008000300011.

Bednarek, P.T. and R. Orłowska. 2019. Plant tissue culture environment as a switch-key of (epi)genetic changes. Plant Cell Tissue Organ Cult. 140:245-257, https://doi.org/10.1007/ s11240-019-01724-1.

Bello-Bello, J., G. García-García, and L.G. Iglesias-Andreu. 2015. Conservación de vainilla (Vanilla planifolia Jacks.) bajo condiciones de lento crecimiento in vitro. Rev. Fitotec. Mex. 38:165-171.

Bello-Bello, J., W. Poot-Poot, L.G. IglesiasAndreu, H. Caamal-Velázquez, and M. Cruz Díaz-Sánchez. 2014. Comparación del efecto de osmorreguladores e inhibidores del crecimiento en la conservación in vitro de caña de azúcar. Agrociencia 48:439-446.

Borbolla-Pérez, V.B., L.G. Iglesias-Andreu, E.A. Escalante-Manzano, J. Martínez-Castillo, M.M Ortiz-García, and P. Octavio-Aguilar. 2016. Molecular and microclimatic characterization of two plantations of Vanilla planifolia (Jacks. ex Andrews) with divergent backgrounds of premature fruit abortion. Scientia Hort. 212: 240-250, https://doi.org/10.1016/j.scienta. 2016.10.002.

Bory, S., M. Grisoni, M.F. Duval, and P. Besse. 2007. Biodiversity and preservation of vanilla: Present state of knowledge. Genet. Resour. Crop Evol. 55:551-571, https://doi.org/ 10.1007/s10722-007-9260-3.

Bory, S., P. Lubinsky, A.M. Risterucci, J.L. Noyer, M. Grisoni, M.F. Duval, and P. Besse. 2008 . Patterns of introduction and diversification of 
Vanilla planifolia (Orchidaceae) in Reunion Island (Indian Ocean). Amer. J. Bot. 95:805-815, https://doi.org/10.3732/ajb.2007332.

Buccellato, F. 2018. Vanilla in perfumery and beverage flavors. In: D. Havkin-Frenkel and F.C. Belanger (eds.). Handbook of vanilla science and technology. 2nd ed. Chapter 19. Wiley Online Library, https://doi.org/10.1002/9781119377320. ch19.

Carvalho, V., D.S. Santos, and C.C. Nievola. 2014 In vitro storage under slow growth and ex vitro acclimatization of the ornamental bromelia Acanthostachys strobilacea. S. Afr. J. Bot. 92:39-43, https://doi.org/10.1016/j.sajb.2014.01.011.

Cruz-Cruz, C.A., M.T. González-Arnao, and F. Engelmann. 2013. Biotechnology and conservation of plant biodiversity. Resources 2:73-95, https://doi.org/10.3390/resources2020073.

Divakaran, M., K.N. Babu, and K.V. Peter. 2006. Conservation of Vanilla species, in vitro. Scientia Hort. 110:175-180, https://doi.org/ 10.1016/j.scienta.2006.07.003.

Doyle, J.J. and J.L. Doyle. 1987. A rapid DNA isolation procedure for small quantities of fresh leaf tissue. Phytochem. Bull. 19:11-15.

Engelmann, F. 2011. Use of biotechnologies for the conservation of plant biodiversity. In Vitro Cell. Dev. Biol. Plant 47:5-16, https://doi.org/ 10.1007/s11627-010-9327-2.

Farreyrol, K., M. Grisoni, M. Pearson, A. Richard, D. Cohen, and D. Beck. 2010. Genetic diversity of Cucumber mosaic virus infecting vanilla in French Polynesia and Réunion Island. Australas. Plant Pathol. 39:132-140, https://doi.org/ 10.1071/AP09072.

Gopal, J., A. Chamail, and D. Sarkar. 2005. Use of microtubers for slow-growth in vitro conservation of potato germplasm. Plant Genet. Resour. Newsl. 141:56, https://doi.org/10.1007/s002990050485.

Hammer, Ø., D.A.T. Harper, and P.D. Ryan. 2001. Past: Paleontological statistics software package for education and data analysis. Palaeontol. Electronica 4:1-9.

Isidro-Adolfo, P., M.F. Netzahualcoyotl, M.T. González-Arnao, L.G. Iglesias-Andreu, and J. Martínez-Castillo. 2019. Assessment of genetic stability during cryopreservation of vanilla ( $V$. planifolia) shoot-tips using ISSR markers. Cryobiology 91:159, https://doi.org/10.1016/ j.cryobiol.2019.10.057.

Keatmetha, W., P. Suksa-ard, M. Mekanawakul, and T.C. Sompong. 2011. In vitro germplasm conservation of Garcinia mangostana L. and Lansium domesticum Corr. WJST 3:33-50, https:// 103.58.148.28/index.php/wjst/article/view/148.

Kendon, J.P., L. Rajaovelona, H. Sandford, R. Fang, J. Bell, and V. Sarasan. 2017. Collecting near mature and immature orchid seeds for $e x$ situ conservation: 'in vitro collecting' as a case study. Bot. Stud. 58(34):1-14, https://doi.org/ 10.1186/s40529-017-0187-5.

Lambardi, M., R. Roncasaglia, A. Previati, A. de Carlo, G. Dradi, F. Da Re, and L. Calamai.
2006. In vitro slow growth storage of fruit rootstocks inside gas-tight or gas-permeable containers. Acta Hort. 725:483-488, https:// doi.org/10.17660/ActaHortic.2006.725.69.

Larkin, P.J. and W.R. Scowcroft. 1981. Somaclonal variation - a novel source of variability from cell cultures for plant improvement. Theor. Appl. Genet. 60:197-214, https:// doi.org/10.1007/BF02342540.

Li, X., G.J. Ahammed, Y.Q. Zhang, G.Q. Zhang, Z.H. Sun, J. Zhou, Y.H. Zhou, X.J. Xia, J.Q. $\mathrm{Yu}$, and K. Shi. 2015. Carbon dioxide enrichment alleviates heat stress by improving cellular redox homeostasis through an ABA-independent process in tomato plants. Plant Biol. 17:81-89, https://doi.org/10.1111/plb.12211.

Lopez-Puc, G. 2013. An effective in vitro slow growth protocol for conservation of the orchid Epidendrum chlorocorymbos Schltr. Trop. Subtrop. Agroecosystems 16:61-68.

Martínez-Castillo, J., P. Colunga-García Marín, and D. Zizumbo-Villarreal. 2008. Genetic erosion and in situ conservation of Lima bean (Phaseolus lunatus L.) landraces in its Mesoamerican diversity center. Genet. Resources Crop Evol. 55:1065-1077, https://doi.org/ 10.1007/s10722-008-9314-1.

Mehrotra, S., O. Khwaja, A.K. Kukreja, and L. Rahman. 2012. ISSR and RAPD based evaluation of genetic stability of encapsulated micro shoots of Glycyrrhiza glabra following 6 months of storage. Mol. Biotechnol. 52:262-268, https://doi.org/ 10.1007/s12033-011-9491-6.

Minoo, D., V.N. Jayakumar, S.S. Veena, J. Vimala, A. Basha, K.V. Saji, K. Nirmal Babu, and K.V. Peter. 2007. Genetic variations and interrelationships in Vanilla planifolia and few related species as expresses by RAPD polymorphism. Genet. Resources Crop Evol. 55:459-470, https://doi.org/ 10.1007/s10722-007-9252-3.

Murashige, T., and F. Skoog. 1962. A revised medium for rapid growth and bioassays with tobacco tissue cultures. Physiol. Plant. 15:473-497, https://doi.org/10.1111/j.13993054.1962.tb08052.x.

Pastelín-Solano, M.C., J. Salinas-Ruíz, M.T. González-Arnao, O. Castañeda-Castro, M.E. Galindo-Tovar, and J.J. Bello-Bello. 2019. Evaluation of in vitro shoot multiplication and ISSR marker-based assessment of somaclonal variants at different subcultures of vanilla (Vanilla planifolia Jacks). Physiol. Mol. Biol. Plants 25:561-567, https://doi.org/10.1007/s12298-01900645-9.

Peng, X., T.T. Zhang, and J. Zhang. 2015. Effect of subculture times on genetic fidelity, endogenous hormone level and pharmaceutical potential of Tetrastigma hemsleyanum callus. Plant Cell Tissue Organ Cult. 22:67-77, https:// doi.org/10.1007/s11240-015-0750-2.

Ramírez-Mosqueda, M.A. and L.G. IglesiasAndreu. 2015. Indirect organogenesis and assessment of somaclonal variation in plantlets of Vanilla planifolia Jacks. Plant Cell Tissue Organ Cult. 123:657-664, https://doi.org/ 10.1007/s11240-015-0868-2.

Ramírez-Mosqueda, M.A., C.A. Cruz-Cruz, J. Atlahua-Temoxtle, and J.J. Bello-Bello. 2019. In vitro conservation and regeneration of Laelia anceps Lindl. S. Afr. J. Bot. 121:219-223, https://doi.org/10.1016/j.sajb.2018.11.010.

Ranadive, A.S. 2005. Vanilla cultivation, p. 25-31. In: Vanilla. First International Congress. Allured Publishing Corporation, Carol Stream, IL.

Rodrigues, P.H.V., F. Arruda, and V.A. Forti. 2018. Slow-grown in vitro conservation of $\mathrm{Hel}$ iconia champneiana cv. Splash under different light spectra. Sci. Agr. 75(2):163-166, https:// doi.org/10.1590/1678-992x-2016-0394.

Sánchez-Chiang, N. and V.M. Jiménez. 2009. Técnicas moleculares para la detección de variantes somaclonales. Agron. Mesoam. 20:135-151, https://doi.org/10.15517/am.v20i1.4989.

Selvakumar, G., G.H. Bindu, R.M. Bhatt, K.K. Upreti, A.M. Paul, A. Asha, K. Shweta, and M. Sharma. 2016. Osmotolerant cytokinin producing microbes enhance tomato growth in deficit irrigation conditions. Proc. Natl. Acad. Sci., India, Sect. B Biol. Sci. 88:459-465, https://doi.org/10.1007/s40011-016-0766-3.

SEMARNAT. 2010. Norma Oficial Mexicana. NOM-059-SEMARNAT-2010. Protección ambiental-Especies nativas de México de flora y Fauna silvestres-Categorías de riesgo y especificaciones para su inclusión, exclusión o cambio-Lista de especies en riesgo. SEMARNAT, CDMX

Soto-Arenas, M.A. 1999. Filogeografía y recursos genéticos de las vainillas de México. Informe final SNIB-CONABIO proyecto No. J101. Instituto Chinoín, A.C., Herbario de la Asociación Mexicana de Orquideología, A.C. México, DF.

Soto-Arenas, M.A. 2006. La vainilla: Retos y perspectivas de su cultivo. Biodiversitas 66:2-9.

Thakur, S., K.L. Tiwari, and S.K. Jadhav. 2015. In vitro approaches for conservation of Asparagus racemosus Willd. In Vitro Cell. Dev. Biol. Plant 51:619-625, https://doi.org/10.1007/s11627-0159706-9.

Trejgell, A., M. Kamińska, and A. Tretyn. 2015. In vitro slow growth storage of Senecio macrophyllus shoots. Acta Physiol. Plant. 37:234, https:// doi.org/10.1007/s11738-015-1983-83-470.

Tyagi, P., S. Khanduja, and S.L. Kothari. 2010. In vitro culture of Capparis decidua and assessment of clonal fidelity of the regenerated plants. Biol. Plant. 54:126-130, https://doi.org/ 10.1007/s10535-010-0019-x.

Verma, P.C., D. Chakrabaarty, S.N. Jena, D.M. Mishra, P.K. Singh, S.V. Sawant, and R. Tuli. 2009. The extent of genetic diversity among Vanilla species: Comparative results for RAPD and ISSR. Ind. Crops Prod. 29:581-589, https://doi.org/10.1016/j.indcrop.2008.11.006. 